Journal of Sustainable Development of Transport and Logistics

journal home page: https://jsdtl.sciview.net

Onyemechi, C. (2019). A supply chain assessment of logistics development drivers of South Eastern Nigeria. Journal of Sustainable Development of Transport and Logistics, 4(2), 32-36. doi:10.14254/jsdtl.2019.4-2.3.

\title{
A supply chain assessment of logistics development drivers of South Eastern Nigeria
}

\section{Chinedum Onyemechi}

Department of Maritime Management Technology

Federal University of Technology Owerri, Nigeria

c_onyemechi@yahoo.com

\section{open access (C) do}

\section{Article history:}

Received: December 25, 2018

1st Revision: May 5, 2019

Accepted: November 22,

2019

DOI:

10.14254/jsdtl.2019.4-2.3
Abstract: Trade facilitation projects of UNCTAD abound in West Africa. However the implementation thereof has rested in the hands of private sponsored agencies working in the region .One of this includes Bordeless West Africa. Programmes has also been instituted to favour port to hinterland trade even though the implementation has been very poor. Proper implementation of trade facilitation programmes in the region thus require immense study of trade movements, supply chain analysis with a view to improving the logistics and transport components of the entire process. Given the above, it makes sense therefore to sensitize the human element components of the logistics sub sector who also are the drivers of the distribution networks in the region on trade facilitation best practices worldwide. With respect to the port sector, the subject of port regulation though new in Nigeria places emphasis on the knowledge sector. The role of the regulator here is to prevent the new oligopolistic ports from acts that reflects monopoly. In this perspective a study that will reduce the port operators monopolistic instincts becomes always necessary. In such a study the port operators will be made to present areas where they have actually adopted inclusiveness policies by outsourcing such activities as tug operations and similar contracts to local operators, in the presence of stakeholders. The other aspect of trade facilitation relative to ports has to do with the role of river ports on the facilitation of hinterland intermodal traffic flow. This aspect is currently referred to as regionalization. In this perspective the regulation of river ports when concessioned and desirable qualities that river port concessionaires should possess will come into play.

Keywords: supply chain, logistics, driver, Nigeria

Corresponding author: Chinedum Onyemechi

E-mail: c_onyemechi@yahoo.com

This open access article is distributed under a Creative Commons Attribution (CC-BY) 4.0 license. 


\section{Introduction}

The zone is known for their outstanding contribution to commerce and trade all over Nigeria. The area is landlocked with few river accesses to the Atlantic ocean. Being a commercial nerve center of trade in Nigeria, the need for transportation at the multimodal level remains on a consistent rise. It is on this vein that the request for a second Niger bridge to the region remains absolutely a necessity In view of the above, traders from the region face enormous challenges in their quest to satisfy the logistics needs of not only the region but of their immediate and remote neighbours from Northern Nigeria who form a network of important cluster in Nigeria's logistics map. Trade with Cameroun through the Niger river in Onitsha via barges have existed for years and may have been deleted from the logistics map based on inadequate vessel bottoms to continue the business. It is on this vein that a refocusing strategy is desirable for the revitalization of the regions international business relationships

\subsection{Objective}

The purpose of the paper is to review to date existing trade facilitation programmes by international agencies like United Nations Convention on Trade and Development UNCTAD as well as assess South East of Nigeria's logistics infrastructural needs in the $21^{\text {st }}$ century.

\section{Literature review}

The traders of South Eastern Nigeria can be analyzed based on existing and developing clusters. The general way of analyzing business clusters is to distinguish them based on supply and distribution patterns of goods as they leave the factory base and as they arrive from the port of entry into the country. This will generally leave us with the following categories: manufacturer, distributor's warehouse, retailer and small market operators and finally the consumer of goods.

Every member of this long supply chain belongs to a common ecosystem and is affected by activities in the supply chain. The constituents of the supply chain includes the logistics drivers namely, facilities, inventory and transport. The others include the cross functional drivers namely; information, pricing and sourcing.

South Eastern Nigeria being a landlocked region is affected by one major logistics driver that is international port whether marine, air or rail. The flow of goods in the present world is such that access to the world is only made easy through the availability of port facilities. South eastern traders have applied the cluster concept and elongated their business ecosystem to other regions of Nigeria both in port cities and adjoining hinterlands. This has been demonstrated in the existence of technical clusters as well as commercial clusters.

Business clusters in the commercial sector includes the information technology sub cluster for the sale of computer parts. Extended vehicle importation and engine parts are part of the technical sub clusters. This cluster has today delved into vehicle manufacture through the establishment of working linkages with Asia. The sector has also delved into the oil and gas local content sub sector with existing enviable ship repair yards in the subsea sector. Thus said, it is clear that the technical success of the South East is indeed a substantial component of technical success in the Nigerian conundrum.

Movement of goods to the East in Nigeria today is dominated by a singular transport mode road transport via a single corridor, the Lagos, Benin Onitsha from Western Nigeria. The level of congestion in this corridor has made transportation to the zone a perennial continuous malady to the Ministry of Transport whose only solution to this dilemma has been a prolonged paper design of East to West rail line. It is a designed contribution of this paper to urge the continuation of this design to move further to a contract awarding level as this will expand the logistics windows available to business concerns in this ecosystem.

The declaration of Enugu airport as an international airport is welcome though the flying fish concept will work well in the region if there are flying facilities in the route. To this end this paper thus calls for the advancement of the Enugu airport to a capable cargo airport with modern facilities. More international airlines should thus be encouraged to ply the route. 


\section{Report of findings}

Basically, elements of the logistics drivers in the supply chain will include facility, inventory and transport. In this sense transport challenges are also part of the logistics challenges. All of the above tailor around one individual, the cargo owner also known as the goods owner or primarily referred to as the shipper. This individual takes responsibility for the damages arising from poor infrastructure. The government who is an external factor provides some of the infrastructure and receives tax for it.

Individuals may also invest though in limited parts of this sub sector. Individuals have in the modern day elongated their participation in facility provision through concessioning. Considering Fig. 1, and beginning from the vehicle, ship or aero plane we assess the south East based on the availability of this carrying unit of transportation in the logistics supply chain. The cargo or unit of trade is conveyed by the vehicle from the origin to its destination as either in bound or outbound good in the supply and distribution chain. In the earlier case the cargo is used as process material for further production services while in the later the cargo moves as finished good as it journeys through distribution channels to the final end user the consumer or customer.

For the south east this has a lot of implications. The relevant question is what level of planning is made to ensure vehicle availability at the intermodal level. Who plans for this sector to ensure adequate availability of vehicle to serve this sector? Leaving this sector to the private sector at the present level of development may not be the best feasible option. It is in this perspective that government has made some input by forming the state and urban mass transit systems. The other question should be; what is the level of inter modality in the sector? At the present level of development it is inadequate. The excess congestion in the Lagos -Benin -Onitsha road supports this claim. It only shows that the road sector is being over used.

An East to West rail network connecting the Aba -Owerri-Onitsha- Agbor-Benin is required. The rail system extended south wards should link Uyo and Calabar and further west from Benin to link main cities in the West such as Lagos. Once put in place rail wagons for cargo transportation should be purchased and concessioned to private operators to ensure effectiveness.

Figure 1: The scheme of concession

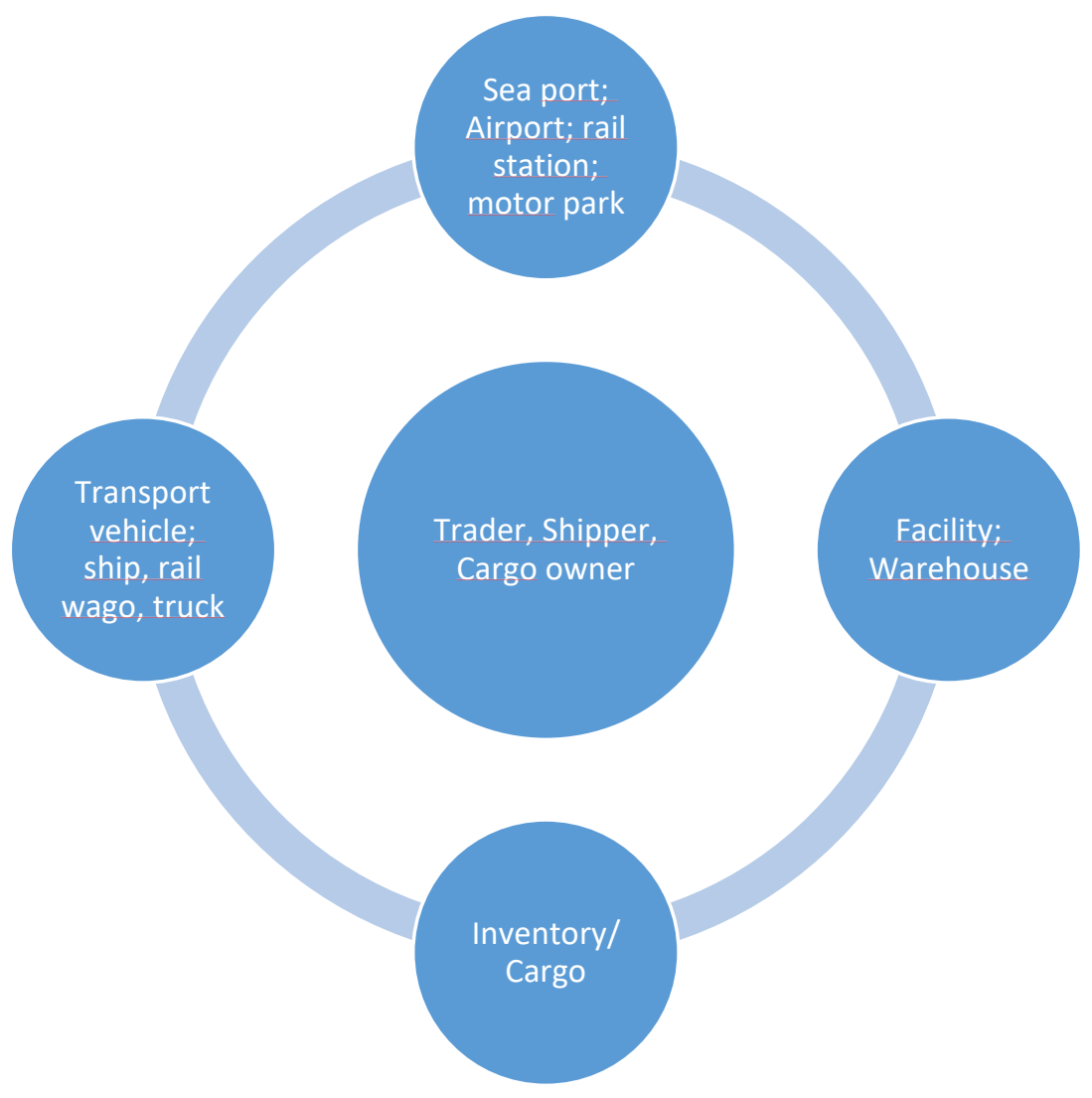


This suggestion complies with the new role which Shipper's council now plays as Nigeria's port regulator in the maritime sector. The role of the port sector as a gateway to the economy has presently extended to being a key initiator of developments in her hinterlands intermodal supply chain. When tackled appropriately, improvements will be realized by the logistics supply chain both in efficiency and in responsiveness. The port improvement aspect of this action will then be in the acquisition of new tributaries to adjacent ports. Presently the Lagos port sector in Nigeria operates like a river without tributaries. The situation can be reversed by creating and operating the recommended rail linkages.

The situation can be reversed by creating and operating the recommended rail linkages. Suggestions in this direction will raise Nigeria's port system presently from its third generation level to becoming a fourth generation port. Agile strategies like the one recommended will make this possible. Shipper's Council can thus invest in the development and implementation of responsive agile strategies as it journeys towards a fourth generation port system.

\section{Summary}

Having presented sea ports together with rail network, the other remaining marshalling areas are the airport and the establishment of special logistics centres and lorry parks. It is the absence of appropriate marshalling areas that has resulted in congested port approaches. The situation also shows up in the road sector causing even further congestion in this over used sector. Nigeria can thus not realize sustainability in her transport sector with these anomalies untreated. Logistics centres must be provided in the port district to help in the marshalling of both inbound and outbound vehicles.

Apart from the ports, these centres should also be provided in cities like Aba, Abia state and Onitsha, Anambra state as further consolidation and deconsolidation areas for cargo vehicles. Provision of loading facilities as well as service facilities for different cargo options in the zone should be made a matter of priority in the centre. Cargo types that require special facilities are refrigerated cargo, and consolidated cargo.

The airport sector on its part should be made available to serve both the passenger and the cargo sub sectors. However, promotional facilities should be applied to attract the best flight services to this major sub sector. The Enugu International airport thus requires special sectors for special cargo such as those demanded by supermarkets, emergency cargo. With proper connectivity to the rail network the airport can be used for emergency logistics to serve the presently developing West Africa's offshore sector when so designated. By so doing the logistics tributary of the airport can thus be expanded.

\section{Appendix A. Supplementary material}

Supplementary data associated with this article can be found, in the online version, at https://jsdtl.sciview.net

\section{Funding}

The authors received no direct funding for this research.

\section{Citation information}

Onyemechi, C. (2019). A supply chain assessment of logistics development drivers of South Eastern Nigeria. Journal of Sustainable Development of Transport and Logistics, 4(2), 32-36. doi:10.14254/jsdtl.2019.4-2.3. 


\section{References}

Hansen, P., \& Annovazzi-Jakab, L. (2008). Facilitating cross-border movement of goods: A sustainable approach. Transit, 3(30.54), 1-741.

Notteboom, T. E., \& Rodrigue, J. P. (2005). Port regionalization: towards a new phase in port development. Maritime Policy \& Management, 32(3), 297-313.

UNCTAD. (1999). Institutional and technological changes in transport/logistics field. UNCTAD/SDTE/TIB/3

UNCTAD. (2004). Assessment of a seaport land interface: an analytical framework. UNCTAD/SDTE/TLB/MISC/2004/3

UNCTAD. (2005). United Nations Conference on Trade and Development.

Cluster Development Guide, March. Geneva: UNCTAD.

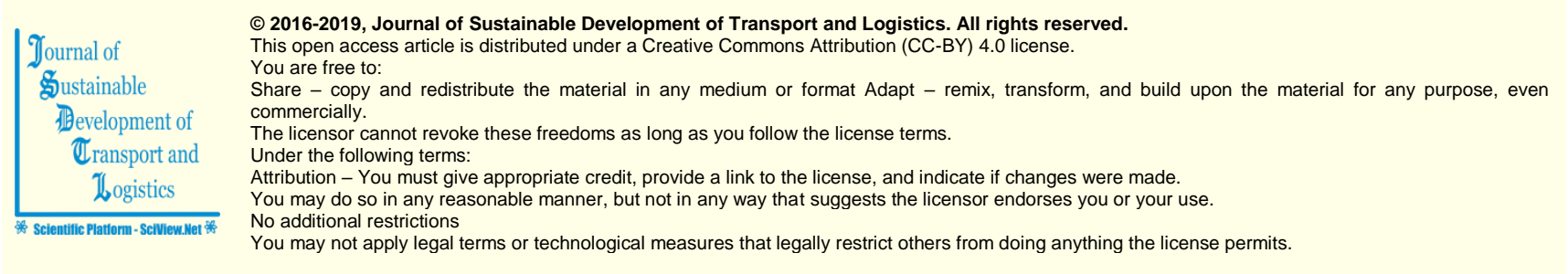

Journal of Sustainable Development of Transport and Logistics (ISSN: 2520-2979) is published by Scientific Publishing House "CSR", Poland, EU and Scientific Publishing House "SciView", Poland, EU

Publishing with JSDTL ensures:

- Immediate, universal access to your article on publication

- High visibility and discoverability via the JSDTL website

- Rapid publication

- Guaranteed legacy preservation of your article

- Discounts and waivers for authors in developing regions

Submit your manuscript to a JSDTL at https://jsdtl.sciview.net/ or submit.jsdtI@sciview.net 